\title{
Towards Strategic Human Resource Transformation \\ In Emerging Economies' Civil Services
}

\section{Dr. Adham ElSherbiny}

\begin{abstract}
This paper aims to firstly, introduce insights for managing the civil service Human Resource Transformation (HRT) strategically. Secondly, to architect a result- based formwork that effectively navigates the SHRT in the civil service's environment and bridges the gap between the current and future civil service capabilities.

The desk research approach was adopted to develop this paper and comprises two main sections. Firstly, a literature review related to change management, agile HR, HRT challenges, and HRT models embraced by private, professional institutions, development agencies, as well as leading international management consulting firms. Secondly, a suggested SHRT framework fits for the civil service's business context.

The research demonstrated and strengthened the rational that failure in HRT programs in the private and public sectors remains a critical issue. The SHRT in the emerging economies countries needs to be engineered and managed differently through a management principals-based framework. The proposed SHRT framework constructed from six core building blocks includes Drivers, Anchors, Enablers, Programming, Stakeholders, and Institution (DAEPSI).
\end{abstract}

Keywords - Strategic Human Resource Transformation, Agile HR, Civil Service.

\section{ملخص}

\section{نحو التحول الاستراتيجي للموارد البشرية بالخدمة المدنية في الاقتصادات الناشئة}

استهدفت الدراسة تقديم رؤية وأفكار مختلفة حول أسلوب استراتيجي لإدارة التحول للموارد البشرية في الخدمة المدنية، وكذللك تصميم إطار للتحول الاستراتيجي للموارد البشرية يستند إلى النتائج، ويُمكن من توفير متطلبات التحول الاستراتيجي للموارد البشرية بالخدمة المدنية، ويسد الفجوة بين الوضع الحالي والقدرات المستهدفة مستقبلا في الخدمة المدنية.

وقد تم استخدام أسلوب الدراسة المكتبية في إعداد هذه الدراسة والتي تتكون من جزئين، حيث يتضمن الجزه الأول الاستعراض المرجعي للدراسة، ويتضدن الجزء الثاني تقديم إطار مقترح للتحول الاستراتيجي للموارد البشرية يتناسب مع نسق الخدمة المدنية. وقد أشارت نتائج الدراسة إلى أن فشل برامج التحول إلى الموارد البشرية مازال يمثل تحدياً كبيراً في الخدمة المدنية والقطاع الخاص، وأن التحول الاستراتيجي للموارد البشرية في الاقتصادات الناشئة يتطلب أن يصمح ويدار بشكل مختلف من خلال إطار شامل مبني على أسس إدارية راسخة. وقدمت الدارسة إطار مقترح للتحول الاستراتيجي للموارد البشرية يضم ستة محاور رئيسية هي المُوجهات، والمُرتكزات، والمُمكنات، وأصحاب المصلحة، والبرمجة، والمؤسسة. الكلمات الدالة: التحول الاستراتيجي للموارد البشرية - موارد بشرية ذكية مبتكرة - الخدمة المدنية 


\section{Introduction}

Since the 1980s, and the rise of the New Public Management (NPM) approach, many countries have undertaken extensive public sector reforms in response to globalization, economic, social and demographic, technological and political changes and pressures. Given that, no single model offers a magic bullet to deep-set problems of public administration reforms in the developing countries (Robinson, 2015). The public perspective regarding the public institutions and the civil service is still not satisfactory. People, policy and systems are identified as distinguished dimensions for public sector reform. Regarding the dimension of people, this area falls within the broader scope of human resource management (Heichlinger, Thijs, Bosse, 2014).

If $\mathrm{HR}$ is not accepted as a transactional function of policy-makers and HR specialists are not allowed a significant role in engaging with or influencing the government's reform agenda, the process of transforming public services will fail. Moreover, Public service transformation is critically dependent on developing new skills, changing engrained behaviors, and managing the uncertainty and conflict that can arise as a result.

Unless HR is involved at the heart of this process to ensure the key people management issues are addressed, public service reform plans will remain frustrated. HR can build and establish its reputation as a key strategic function if it is at the heart of managing change, helping to facilitate service delivery redesign, and building the necessary leadership and management skills for sustained public service transformation (HRM Guide, 2011).

The use of strategic human resource management in public service relates to changes in the administrative systems on a larger scale. The reasons for the durability of the Human Resource Management (HRM) can be explained by the fact that it addresses strategic HR issues both at the micro and macro levels of public service (Järvalt, 2012). The micro-level is related to a single public service organization, whereas the macrolevel incorporates the entire public service, which in many countries is considered to be one entity and is often also regulated by a specific public service law. (Perry, Wise, 1990).

Moreover, the civil service is defined first by function, referring to the central, "upstream" agencies who set policy direction and procedural regulation for the "downstream" agencies, second by entities ownership by the government. The scope, responsibilities, functions and organization of the civil service varies across countries (International Civil Service Effectiveness Index, 2017). A contradictory view of similarity versus dissimilarity between the private and public organizations was recognized (Järvalt, Randma-Liiv, 2010). Moreover, there are three distinctive features that lie at the heart of the HRM and performance debate within the public sector including; the nature of organizational performance, the nature of HRM, and the linkages between the two (Knies, et al, 2018). Hence, adopting private sector HR practices in the civil service is too simplistic. 
A research conducted in 18 countries has found that 74 percent of private-sector transformation efforts fail to meet their objectives, while in the public sector, the failure rate is even higher, at 80 percent (Checinski, et al.,2019). Another study showcased that eight out of ten large companies are running a program to reduce the cost of their HR function. Yet, less than $20 \%$ of all HR transformation programs produce the desired results. It's a painful truth; HR transformation rarely transforms HR (Adams, 2018). Resistance to change and to HRT in the public-sector is not less challenging than in the private sector; it could even be harder. Taking this into account, there is not one model for delivering HR that is suited to all organizations (CIPD, 2015).

The research problem can be articulated as "The civil service in the emerging economies countries are still struggling to achieve true HRT". Emerging economies countries refer to nations that are investing in more productive capacity. They are moving away from their traditional economies that have relied on agriculture and the export of raw materials. They are rapidly industrializing and adopting a free market or mixed economy (Amadeo, 2019). This paper addresses the SHRT in the emerging economies countries due to the recognized political will, the civil service reform becoming their priority, the capable human capital availability and the economic capabilities to implement the comprehensive SHRT initiatives. The main argument question of this paper is, therefore "How could HRT be structured and managed defiantly to achieve true HRT in the emerging economies countries' civil service?". It is also worth noticing that the terms "public sector", "civil service", and "public service" in this paper may be used inclusively, interchangeably and spontaneously.

\section{Literature Review}

\subsection{Change and Transformation}

Organizations use the word transformation while they actually mean change, and vice versa. They use these words interchangeably. It is vital to understand the difference between these two. Both are good and necessary for the organization, but the goal, outcome, processes, and way of thinking are different. When in change mode, it is the desire to improve the past that directs what we do. In transformation mode, it is the future that will direct our actions and only the limitation of our imagination and courage constrains the possibilities. Change uses external influences to modify actions, while transformation modifies beliefs so actions become natural and thereby achieve the desired result. Change is required for transformation, and all transformation involves change, but not all change is transformational (Chaudron, 2019).

\subsection{Change Management}

Several change management models (e.g. ADKAR and Kotter) developed to provide a roadmap for organizational change. Time, scope, capability, and capacity are the main factors that should be considered before making the change (Naghibi, Baban, 2011).

\subsection{Strategic Organization Change Management}

The flexible strategic model of change management process involves deciding in advance to be prepared to alter organizational structures, procedures for decisionmaking, services offered, client groups served, suppliers used and new knowledgebased organizational context implemented. Managing strategic change involves three elements that interact continuously with each other include the context, content, and process. 
The context refers to the "why" of change question; the content answers the questions "what" actions will be required; whereas the process applies to the questions "how" these actions will be implemented. The strategic change management process is an evolutionary process rather than revolutionary; it is crafted rather than planned. Organizational success is not about predicting and following trends; it is about anticipating imminent deviations from trends and taking pre-emptive actions (Penger, Tekavčič, 2008).

\subsection{Agile Public Sector Organization}

Agile management is now a vast global movement that is transforming the world of work. The agile movement took off in software development in 2001 and is now spreading rapidly to all parts, and all kinds, of organizations. Despite scores of different labels and flavors of agile, organizations that have successfully embraced agile embody a mindset that includes three core characteristics or principles including; the primacy of the customer, descaling work for small teams, and the organization as a network.

(Denning, 2018). Organizational agility is defined as an "emerging management concept that prepares the organization to make rapid decisions in the dynamic and unpredictable market-dominating today" (Van Hoek, Harrison, Christopher, 2001).

Similarly, to the private sector, public sector organizations could benefit from the application of this concept particularly in light of the rapid ongoing technological advancements that affect both the corporate and public landscapes in many ways. The need to adopt organization agility in the public sector is specifically driven by the need to understand and respond to changing citizen demands and the emergence of rapid technological breakthroughs. Switching to agile organizations requires the adoption of very specific principles. These types of organizations have a culture and a mindset that focus on strategic thinking, exploration of innovations, and pro-activity. In addition, teams in agile organizations are cross-functional, share a common purpose, work collaboratively, and build on each other's skillsets to deliver desired quality outcomes. Those teams have distinct communication rules that allow and endorse efficient flow of information which helps organizations react faster and seamlessly to changes. (Aoun, 2018). When HR is included and buys into the values of organizational agility, the promise of increased productivity, efficiency, and higher-quality products and services can be fully realized (Gothelf, 2017). Hence, it is vital to understand the role of human resource management in organizational agility.

\subsection{Agile Human Resource}

Over the last three decades, HR evolved through four phases. It started from an "operational role" (the personnel department) to "HR as a service center" to HR which focused on "driving talent outcomes" to the last phase of the "high-impact HR" focusing on changing the operating model to be less centralized and more "coordinated but distributed" into the business. The core of high-impact HR today is creating more specialists and locating them closer to the business where they can drive the most value, relying on standard technology platforms, standard frameworks and standard tools to help HR professionals to become closer to the business to solve their problems (CIPD, 2015).

Historically HR has focused very much on standardization and "one-size-fits-all". It is difficult to make the shift to an approach where the individual needs, wishes, and capabilities of candidates and employees are the starting point (Haak,2019). Then, the 
agile approach was introduced to help organizations improve their agility through the HRM strategy and practices. Taking into consideration that, agile HR refers to:

- a way of working and organizing the HR function that facilitates responsiveness and adaptiveness of activities and structures,

- facilitating the flexibility in matching workforce fluctuations to demand, and

- the way the HR function supports the organization in becoming more responsive and adaptive (HR Trend Institute,2019)

With agile HR, the traditional focus on control and alignment has shifted to a more agile focus on speed of responsiveness and customers. The journey to achieving true agility is not a quick one and requires continual hard work and scrutiny. In creating the right conditions for agility, HR needs to be on its toes (Roper, 2016). Harvard Business Review (HBR) cited the potential agile HR practices to include performance evaluation, coaching, teams, compensation, recruitment, and learning (Denning, 2018).

\subsection{Agile Human Resource in the Public Sector}

Strategic agility has three main dimensions: strategic sensitivity, resource flexibility, and leadership unity. Resource flexibility is not only about budgets, but also about ensuring that the right human resources can be acquired, developed, and deployed in line with shifting priorities. OECD countries have been using a range of strategic HRM practices to help them align their people management with the strategic goals of public sector organizations. These practices not only help governments meet strategic objectives but also contribute to agility by increasing efficiency, responsiveness, and quality in service delivery. Strategic HRM also encourages governments to look to the future, thinking strategically about the right mix of people and skills that will be needed to respond to changing societal needs. These practices include strategic workforce planning, skills, and competency management, promoting greater mobility in the public service, targeted recruitment and hiring, using performance management and compensation as incentives, fostering diversity, and changing the public service culture (OECD, 2015).

\subsection{Human Resource Transformation in the Public Sector}

Many countries are experiencing a crisis in public-sector human resource management stemming from mounting pressures on numerous fronts. Budgets are tight for numerous governments around the world; human capital costs represent about $25 \%$ of government budgets on average (they are even higher, at about 30\%, in Africa, the Middle East, and Central Asia). In addition, demands on government staff are increasing because of a growing need for services in some countries and rising expectations for government performance among citizens in general. At the same time, a looming retirement wave in many countries is creating a potentially problematic loss of institutional expertise. All this is playing out at a time when governments must upgrade their talent base. This includes recruiting people with the skills to help them deploy new digital technologies, an area where talent is in limited supply and for which there is tremendous competition (Audier, et al., 2016). To identify the nature of the civil service and assess the change necessary to reform the civil service of a country, a four quadrants civil service model was developed, which includes;

- The pragmatic field: Where the state is highly institutionalized, the public opinion is basically anti-state and the civil service is more professional and process-oriented (e.g. USA); 
- The patrimonial field: Where the state is relatively "inchoate" or noninstitutionalized, public opinion is still basically anti-state and the civil service is more politically responsive, but still process-oriented (e.g. Nigeria);

- The positivist field: Where the state is relatively highly institutionalized, the public shares a more pro-state orientation, and the civil service is more outcomes-oriented and professional (e.g. France, Japan, and South Korea);

- The absolutist field: Where the state is less institutionalized, the public is relatively more pro-state, and the civil service is more outcomes-oriented and politically responsive (e.g. China from 1949-66). When a country undertakes reforms, the state-society relations change; as civil services become more professional, countries move from one field to another (Iqbal, 2006).

In the 1990s, the concept of HRT evolved and referred to the re-engineering of HR structure, processes, and outcomes. HRT is defined as a "radical effort to change, rethink, reinvent, and reposition HR's role in the organization" (Rothwell, et al., 2008). Moreover, the true HR transformation is defined as "an integrated, aligned, innovative, and business-focused approach to redefining how HR work is done within an organization so that it helps the organization deliver on promises made to customers, investors and other stakeholders" (Ulrich et al.,2009).

\subsection{Human Resource Transformation Challenges in the Public Sector}

There are several reasons why HR transformation efforts often fail, include:

- Lack of political will and support to carry on the process of a civil service reform;

- Civil service is more often viewed as a problem rather than as a solution;

- Bureaucratic resistance;

- The politicization of bureaucracy;

- Inter-hierarchical rivalry;

- Disproportionate reform measures with the capacity of the government to implement them (Shakya, 2009).

Additional reasons for HRT failure also identified from the private sector practices, are still valid in the public sector, include:

- Action before rationale: by doing things in HR are not tied to a business rationale and are rooted in the business context;

- HR in isolation: when an HR strategy is drafted in isolation from the business strategy;

- HR in increments: by designing innovative talent management; performance management and declare it an HR transformation. These piecemeal efforts are only part of an HR transformation;

- HR by individual fiat: by investing in an HR transformation because of the whims of an individual leader or the desire for more personal or functional influence;

- Placing HR structure before business strategy: HR transformation can only be complete as it helps implement the business strategy and drives business results;

- Efficiency equals transformation: efficiency improvements can and usually are key elements of transformation, but efficiency alone does not make for transformational change (Ulrich, et al., 2009). 


\subsection{Human Resource Transformation HRT Models}

During the last two decades, several HRT models were introduced by private, professional institutions, development agencies, and leading international management consulting firms:

\subsubsection{Dave Ulrich Model}

This is the leading model in the field of HRT, the model's four phases to build the business case for transformation, define the outcome, redesign HR, engage line managers, and others in defining and delivering the transformation (Ulrich, et al.,2009).

\subsubsection{Krishna \& Prasad Model}

The model consists of four dimensions- Business Context, Outcome of the HRT, HR Redesign, and HR Accountability (Krishna, Prasad, 2012). This model is recognized by focusing on HRT link with HR accountability when strategies translate into measurable results.

\subsubsection{The Business Partnering Model}

The "three-legged model" is based on three key elements- HR business partners, HR Shared Services, and HR Centers of Excellence. This model is a popular and widespread approach to organizing the HR function (CIPD, 2014). As well as, it enables HR to get closer to business units while balancing more cost-effective, scalable service solutions.

\subsubsection{Boston Consulting Group's HR Transformation Approach}

This approach recognized by six complementary modules - people / HR strategy, HR processes and governance, HR organization and sizing, HR staff capability, HR system and tools, and change management and implementation. These modules reflect a comprehensive and interrelated approach as the basis for success. (Boston Consulting Group, 2019).

\subsubsection{Deloitte's High-Impact HR Operating Model}

The model's ten core elements encompass HR customers, digital workplace, workforce Insights, the model's strength, HR operational services, business HR, communities of expertise, external networks \&partners, HR leadership partners, and HR enablers. This model distinguished by:

- Aligning the work an organization needs with the capabilities to deliver it most effectively;

- Incorporates digital as an integral part of the operating model to empower and connect with the workforce;

- Emphasizes coordination within and beyond HR;

- Reshapes the roles and responsibilities within HR and the ways HR interacts inside and beyond the enterprise's walls;

- Establishes HR's critical new role in fostering connections outside the organization. (Deloitte,2017)

\subsubsection{Mercer's HR Transformation Framework}

The framework characterized by a design of three main steps:

- Understand the starting point, this step includes current, future, and roadmap. 
- Set the strategic direction for design, this step includes business strategy, people strategy, HR functions strategy, HR operating model, and performance monitoring.

- Design infrastructure to support the new strategy and direction, e.g. technology, people, and outsourcing (Mercer, 2012).

2.9.7. The International Public Management Association (IPMA) framework

This framework uses three critical lenses for HRT - business acumen, innovation, and strategic orientation. The framework characterized by five areas of focus to maximize the impact of transformation including leadership, culture, talent, communication, and technology. These areas of focus encompass the HR professions' most critical and widespread service gaps that must be addressed (IPMA-HR,2016).

\section{The proposed Strategic Human Results Transformation SHRT framework}

The proposed DAEPSI framework developed based on key management principles including agility, people \& citizen centricity, results \& future orientation, holistic approach, value criterion, sustainability, and scalability. DAEPSI framework constructed from six core building blocks as described in the following figure:

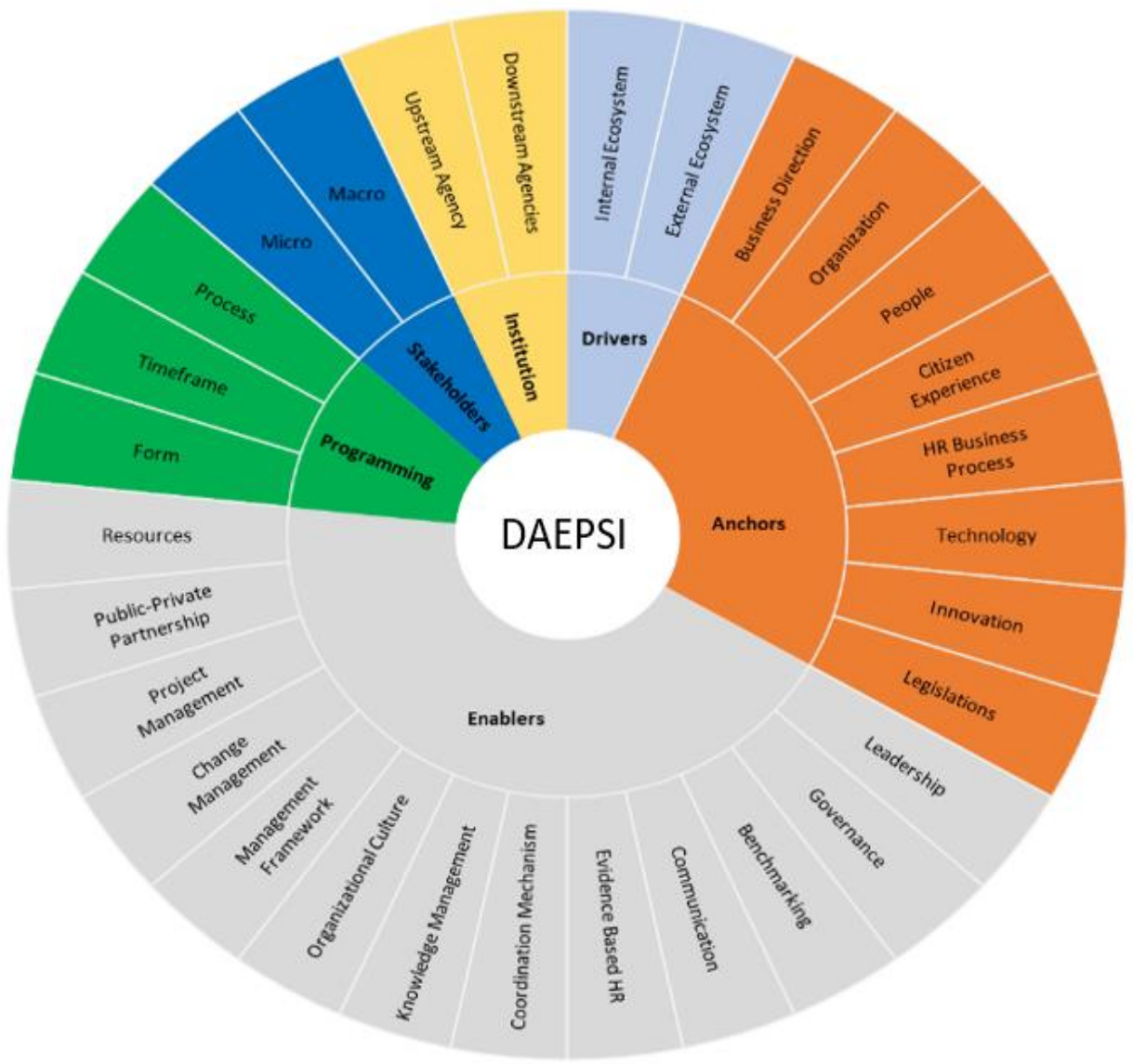

Source: Developed by the author

\subsection{Drivers- Why SHRT?}

Identifying SHRT drivers is critical because transformation cannot be embarked in isolation from the civil service ecosystem and the holistic business context.HR is maintaining its stability and focus despite disruption, being adaptable in the face of disruption, and in turn helping the business be stable and adaptable in its response to 
disruption. (Gretczko, 2016). PESTLIED (i.e. political, economic, socio-cultural, technological, legal, international, environmental, demographic factors) approach (Cadle, Paul, Turner, 2010) can be adopted to assess the external status quo of the global, national, government and industry ecosystem. The organization's internal environment assessment including the HR department is also central. Several tools (e.g. EFQM excellence model and McKinney's organizational health index) can be adopted.

\subsection{Anchors - What are the anchors of the SHRT?}

The anchors of DAEPSI framework represent the most substantive areas to formulate the landscape of civil service as a result of SHRT. These anchors are:

- Business Direction: Start with the end as a launching point to navigate the SHRT journey, invest in setting and visualizing clear future destinations linked to the national strategy, identify how success looks, lead the HR business direction to sensitively translate the strategic objectives into a realistic transformation ambition.

- Organization: Agile organization characterized by:

- Future-oriented and responsive;

- Planned and managed to ensure the right skills and competencies are effectively allocated to areas of current and emerging need;

- Able to structure the right balance of generalist and specialist professions and career paths;

- Capable of integrating soft skills and ethics;

- Attractive to skilled job seekers;

- Open, autonomous, mobile, and diverse (OECD, 2017).

- Safeguard the merit and non-partisan civil service;

- Able to embrace slim and less hierarchical organizational structure;

- The HR strategy is aligned with organization objectives, outcomes, and values;

- Real-time and ongoing performance management supported by coaching;

- Adopt strategic workforce planning, succession planning as well as the hybrid position and career-based hiring systems;

- Fostering mediation as an alternative dispute resolution;

- Facilitate autonomy by delegating HR responsibilities from the central HRM bodies to the governmental institution HR departments;

- Properly manage employee wellbeing and engagement;

- Effectively deliver HR services through several channels (i.e. shared service, outsourcing and community of experience);

- Capable teams who are multidisciplinary, have their own end-toend responsibility, and free to experiment.

- People: the future civil service needs civil servants who are qualified, independent, value-driven, ethical, evidence-based, future-oriented, outcomesdriven, proactive, networked, iterative, data literate, citizen-centered, curious, storytellers, and insurgent (OECD,2017). The future people-centric strategy to unleash people potentials can be addressed by:

- Building, empowering and propelling the human capital capabilities;

- Personalizing employees experience and work-life integration;

- Prioritizing diversity and inclusion;

- Enabling employee participation in decision making within their organization; 
- Supporting fairness, compassion, motivation, rewarding and recognition;

- Promoting mobility and developing the capabilities of senior executives who lead and manage the pace and cadence of SHRT. Whereas, professional, strategic and innovative civil service needs senior civil servants who are trusted policy advisors, effective transactional managers, transformational leaders, change managers, collaborative leaders and adaptive managers (OECD,2017);

- Enhancing talent acquisition and creating an integrated talent management system enables the understanding of future capabilities requirements across the government, building an agile workforce, anticipating leadership transitions, as well as understanding and mitigating talent-related risks. Also, developing and communicating clear targeted value propositions to attract the right talent in a competitive market (McKinsey \& Company,2017);

- Facilitating career development as well as continuous blended learning and development. The future HR department competencies include relationship management, communication, business acumen, consultation, leadership and navigation (Jones, 2016);

- Maintaining resilient HR professionals who are capable to carry situational judgments, social and ethical responsibility, being a body of knowledge and skills, and committed;

- Considering the generational shifts and needs;

- Preparing for the shift in the work environment (i.e. Human- robotics hybrid workforce, remote work), activities, and collaboration.

- Citizen Experience: Governments around the world are taking proactive measures to upscale people, technology, and processes in the public sector to match the rising expectation of their citizens. Innovation, service redesign, and co-creation, backed by strong customer analytics and service culture, have emerged as the prerequisites to drive citizen-centric transformation (Ernst \& Young, 2017).

- HR Business Process: A coherent, integrated and efficient set of HR processes guidelines (i.e. roles, responsibilities, policies, procedures, reporting lines and decision rights) need to be redesigned (i.e.to be clear, simple, streamlined with artificial intelligence, fixable, end-to-end, and standardized), aligned with the organization' desired business outcomes and well communicated to all the organization' stakeholders.

- Technology: In the era of the fourth industrial revolution, HR technology and digitalization becomes the transformation breakthrough. It is major to address the lack of integration across HR systems, provide real-time HR services, build the organizational capacity, and foster transparency.

- Innovation: HR professionals are well-positioned to become innovation leaders. They have a unique and comprehensive view of the organization and as such can assist in finding efficiencies and other opportunities to streamline operations and deliver services more effectively (IPMA-HR, 2016). People's active participation in SHRT especially the youth will generate innovative solutions for transformation and foster buy-in at all levels. Innovation Lab, design thinking, gamification, and blockchain need to be considered for continuous improvement and maximizing productivity.

- Legislations: A modified set of disciplines aligned with the SHRT objectives need to be introduced at the macro and micro levels to enhance desired behavior. 
Without legislative reform and enforcing the law, true HRT will not be accomplished.

\subsection{Enablers- How to manage the SHRT?}

This corner building block equips the tools and practices on how to effectively and efficiently manage the SHRT journey. These enablers are:

- Leadership: At the macro level, it is critical for the SHRT to be led and sponsored by explicit, trusted, responsible, sustainable, and transformational leadership. Serious political will is to be considered to remove obstacles and adopt the right mindset, engaging with the public, and keeping the momentum of transformation. The buy-in and sustainable engagement of senior executive civil servants, middle management, line managers, and HR leaders of the governmental agencies are pivotal to foster creative and effective stewardship.

- Management Framework: Results-Based Management (RBM) has become a global trend in public-sector development to enable public-sector organizations to monitor their effectiveness in achieving their target goals and objectives, promote the accountability of all stakeholders in the achievement of results, and enhance productivity through more efficient resource utilization (Asian Productivity Organization, 2015). RBM implemented successfully in the public sector in many developed and developing countries (Pazvakavambwa, Steyn, 2014) and the promotion of results-based management was recommended by the World Bank to support civil service and administrative reform for the bank member countries (Evans, 2008). The theory of change is a fundamental part of managing for results and reinvigorates the analytic roots of RBM. Which defined as a "life-cycle approach to management that integrates strategy, people, resources, processes, and measurements to improve decision-making, transparency, and accountability". RBM approach focuses on achieving outcomes, implementing performance measurement, learning, and adapting, as well as reporting performance. RBM relies on core concepts, including results orientation, appropriate analyses, contribution and influence, results-based monitoring and evaluation, continuous adjustment, managing risk, and lessons learned (Global Affairs Canada ,2016).RBM approach can be cast in seven steps, of which the first four relate to results-oriented programming includes: defining the contribution to the higher-level expected results, analyzing the needs to be addressed and issues to be tackled, designing results frameworks and in particular formulating expected results, developing an implementation strategy, monitoring progress towards the expected results, evaluation and reporting (UNESCO,2015). Moreover, embracing of Rapid Results Approach (RRA) as a tool for implementing RBM in the public service is therefore consistent with the focus on results, capacity enhancement, and client ownership. RRA accelerates the implementation of plans and priorities, builds support for large-scale change efforts (Sylvester, 2008).

- Governance: To maintain the control of business rules, establish clear guardrails, and convey expectations to the HR workforce, a responsive governance structure need to be developed and activated.

- Benchmarking: The characteristics and attributes of benchmarking include measuring performance, systematically identifying best practices, learning from leading organizations, and adapting best practices as appropriate (IPMA-HR, 2017).

- Communication: Before launching any SHRT initiative, a coalition network of the SHRT stakeholders at the macro and micro levels need to be established. 
Having a clear and positive understanding of the SHRT goals, agenda, challenges, and how to address it with the citizens and civil servants across at all levels is vital. Facilitating continuous community dialog and using the right messages at the right time by the right person through the right channel is required to ensure the success of SHRT at all levels.

- Evidence-Based HR Practices: In the current and future unpredictable business climate there is a greater need than ever for HR to be data-driven. Adopting HR analytics as a necessary step toward evidence-based HR (Van der Togt, Rasmussen, 2017) approach will foster proactive, better-informed, and consistent decision making.

- Coordination Mechanism: Synergy and collaboration between and within the governmental institutions at the macro and micro levels is substantive for role and responsibility clarity, alignment, and bringing people together for efficient and effective SHRT.

- Knowledge Management: To build an effective learning organizational culture, Knowledge management needs to become an explicit goal of future public service reform (Lodge, Kalitowski, 2007). Knowledge transfer and integrating lessons learned into decision making is important for continuous improvement.

- Organizational Culture: Culture can be predetermined as it is significantly affected by nationality, type of industry, the structure, and control system within an organization (Hofstede, et al. 1990). The future positive practices of organizational cultures will center around three core interdependent values include caring, learning, and innovation (IPMA-HR, 2016). Although changing culture is challenging, several cultures (e.g. continuous improvement, experimentation, performance accountability, engagement, commitment, and productivity) need to be fostered.

- Change Management: Managing resistance to change, changing people's mind-set and behaviors are the main challenges facing SHRT ambition and endeavor. The key is to manage change in such a way that employees view this as an opportunity, not as a threat (Mulholland, 2017).

- Project Management: The SHRT initiatives at all levels need to rest on the project management approach.

- Public-Private Partnership: The contribution of the private sector and Nongovernmental organizations NGOs can effectively support the public service SHRT efforts. Public-Private Partnership makes better use of external contracting, volunteering, and partnerships to gain more flexible access to complement government expertise (McKinsey \& Company, 2017).

- Resources: The efficiency of managing the available resources (i.e. fund, technology, human capital, tools, and timeframes) is a challenging factor especially for emerging economic countries. Zero-Based Budgeting is considered to confront conventional thinking and resource allocations by challenging every line item and assumption, fund key strategic imperatives while removing large non-value-adding costs, align resources with the mission of the function and enterprise as well as justify proposed activities and resources (Rigby,2015).

\subsection{Stakeholders - Who are the SHRT stakeholders?}

Engaging the proper key partners during the SHRT journey is required. The SHRT multiple stakeholders are; 
- The macro-level stakeholders include; the government, political leaders, think tanks, international development agencies, parliaments, citizens, parties, unions, professional syndicates, mass, and social media, civil service leaders, Non- governmental organizations (NGOs), universities, research institutes, and private sector representatives.

- The micro-level stakeholders include; SHRT team (HR leaders, professionals, and project management office PMO), line managers, senior executives, leadership at all levels of the organization, and employee representatives.

\subsection{Programming- When the SHRT process take place?}

The SHRT programming components are:

- The SHRT Form: The SHRT initiative takes the form of well-connected programs. Each program comprises a portfolio of interdependent or intersecting result-based projects able to be piloted, adapted, adopted, replicated, scaled-up and institutionalized. This form will foster quick wins and iterative progress towards SHRT expected results.

- The SHRT Timeframe: It is well recognized that transformation takes time and needs to remain relatively fixable. Meanwhile, over or underestimating the timeframe needed for the transformation is not efficient. Aligning the timeframe of the SHRT programs with the government plan (usually five years' plan) and the central civil service agency plan will be a privilege to effectively manage the transformation process. The pace of SHRT process and interventions will be determined according to the country's context, the central civil service and the government organization's capabilities, and the HR department's maturity.

- The SHRT Process: Seven phases formulate the SHRT process as follows:

- Inception: This phase address architecting and organizing the SHRT program and projects. Therefore, several deliverables need to be developed and documented include, networks and stakeholders' analysis, diagnostic study, benchmarking, the business case (identifying benefits, Value for Money, dependences and risks), human capital strategy, SHRT strategy\& roadmap, communication plan, change management plan, risk management plan, action plan, monitoring \&evaluation methodology, exit strategy, the coordination mechanism, teaming the SHRT task force as well as identifying roles and responsibilities.

- Plan\& Design: This phase address setting the SHRT programs and project priorities, figuring solutions, developing the project's performance management frameworks, mobilizing resources, and recruiting project staff.

- Act: This phase includes the parallel and sequent execution of the programs and projects according to the project's design, level of majority, priority, and independency.

- Stabilize: This phase address managing resistance, handling negative changes, and ensuring that any deviation or reversible practices could affect the targeted positive transformation is not occurred.

- Sustain: This phase address recognizing the quick wins, people commitment, institutionalizing the transformation results in the business process and day-to-day practices, as well as rooting the execution discipline of transformation to maintain the sustainment of transformation.

- Expand: This phase address augmenting the capability for scalability and replication at the macro and micro levels. In addition to share the 
transformation results and lessons learned with the SHRT stakeholders at all levels.

- Monitoring \&Evaluation: Continuous measurement of the progress towards the SHRT expected results is essential for transparency and future improvements.

\subsection{Institution - Where the SHRT take place?}

Identifying the role and responsibility of the deferent institutions involved in SHRT is critical. The categories of institutions are:

- The central "upstream" civil service agency who lead the SHRT at the macro level and act as legislator, regulator, enabler, and facilitator.

- The "downstream" governmental agencies and its HR departments are

\section{Conclusion} responsible for implementing the SHRT programs at the micro-level.

As the pace of business change accelerates especially after COVID -19 pandemic, disruptive economies drive governments to operate like competitive enterprises to meet the public's needs and expectations. People and citizens should always be in the center of any government reforms and civil service transformation. HRT is not a new topic.

Yet it has remained a critical issue and the most common buzzword in organizations today. Given that, to achieve true HRT it needs to be engineered and managed strategically. The SHRT has become a game-changer however it is a continuous, complex, and costly journey and not an objective in itself. Hence, SHRT can be defined as a "structured sustainable approach to navigate the HR transformation journey towards agile HR, aligning people management and business outcomes as well as creating future value to the organization".

Although DAEPSI framework has been focused on the emerging economies' civil services HR, it can be modified and adapted in the private sector and NGOs.

Evidence of failure in HRT programs in the private and public sectors was recognized for the past three decades and still a critical issue, further research is needed to consolidate learning in the field of SHRT mainly in the emerging economies and developing countries. 


\section{References}

- Adams, L. (2018). HR Transformations Don't Transform HR. Retrieved from https://disruptivehr.com/hr-transformations-dont-transform-hr/

- Amadeo, K. (2019). Emerging Market Countries and Their Five Defining Characteristics. Retrieved from https://www.thebalance.com/what-are-emerging-markets-3305927

- Aoun, H. (2018). Agile in the Public Sector, Deloitte. Retrieved from https://deloittemiddleeastmatters.com/2018/05/03/agile-in-the-public-sector/

- Asian Productivity Organization. (2015). Results-based Management for Public-sector Organizations, Vietnam National Productivity Institute, Hanoi. Retrieved from https://www.apo-tokyo.org/publications/wp-content/uploads/sites/5/2015 Jul-Aug_p5b.pdf

- Audier, A. , Caye, J. , Robieux , L., Strack, R. , Von der Linden C. ,Werfel, D. (2016). Creating People Advantage in the Public Sector, Transforming Government Human Resources, Boston Consulting Group BCG. Retrieved from https://www.bcg.com/publications/2016/people-organization-creating-people-advantage-publicsector.aspx

- Boston Consulting Group. (2019). HR Transformation Approach, Six complementary modules. Retrieved from http://www.bcg.com/expertise/capabilities/people-organization/hr-transformationapproach.aspx

- Cadle, J., Paul, D., Turner, P. (2010). Business Analysis Techniques, 72 Essential Tools for Success, British Informatics Society Limited (BISL). Retrieved from https://bcs.org/upload/pdf/business-analysis-techniques.pdf

- Chaudron, M., (2019). Change vs. Transformation, Rock 'n Change. Retrieved from https://rocknchange.com/change-vs-transformation/

- Checinski, M., Dillon, R., Hieronimus, S., Klier,J. (2019).Putting people at the heart of publicsector transformations. McKinsey \& company. Retrieved from https://www.mckinsey.com/industries/public-sector/our-insights/putting-people-at-the-heart-ofpublic-sector-transformations

- CIPD. (2015). Changing HR operating models. Retrieved from https://www.cipd.co.uk/Images/changing-operating-models tcm18-10976.pdf

- CIPD. (2014).HR business partnering factsheet. Retrieved from http://aspirehrbp.org.uk/wpcontent/uploads/sites/51/2016/11/HR-business-partnering-Factsheets-CIPD.pdf

- Deloitte. (2017). High-Impact HR Operating Model. Retrieved from https://www2.deloitte.com/global/en/pages/human-capital/articles/high-impact-hr.html

- Denning, S. (2018). Can HR Become Agile? Forbs. retrieved from https://www.forbes.com/sites/stevedenning/2018/03/11/can-hr-become-agile/\#72592b904ae3

- Ernst \&Young. (2017). Driving citizen centricity. Retrieved from https://www.ey.com/Publication/vwLUAssets/EY-what-is-driving-gcc-governments-to-deliverbetter-citizen-experiences/\$FILE/EY-what-is-driving-gcc-governments-to-deliver-better-citizenexperiences.pdf

- Evans, A. (2008). Civil Service and Administrative Reform: Thematic Paper. Retrieved from http://docplayer.net/38651452-Anne-evans-civil-service-and-administrative-reform-thematicpaper.html

- Global Affairs Canada. (2016). Results-Based Management for International Assistance Programming at Global Affairs Canada: A How-to Guide, Second Edition. Retrieved from https://www.international.gc.ca/world-monde/assets/pdfs/fundingfinancement/results based management-gestion_axee resultats-guide-en.pdf

- Gothelf, J. (2017). How HR Can Become Agile (and Why It Needs to), SHRM. retrieved from https://www.shrm.org/resourcesandtools/hr-topics/technology/pages/how-hr-can-become-agileand-why-it-needs-to.aspx

- Gretczko ,M. ( 2016). The path to HR sustainability, From the digital workplace to digital HR to sustainable HR, Deloitte Consulting. Retrieved from https://capitalhblog.deloitte.com/2016/10/26/the-path-to-hr-sustainability/

- Haak, T. (2019).10 inspiring HR Trends for 2019. HR trend institute. Retrieved from https://hrtrendinstitute.com/2018/11/26/10-inspiring-hr-trends-for-2019/

- Hofstede, G., Neuijen, B., Ohayv, D., Sanders, G. (1990). Measuring Organizational Cultures: A qualitative and quantitative study across twenty cases. Administrative Science Quarterly, Vol. 35, No. 2, pp. 286-316 
https://www.scirp.org/(S(i43dyn45teexjx455qlt3d2q))/reference/ReferencesPapers.aspx?Referenc eID $=26697$

- Heichlinger, A., Thijs, N., Bosse, J. (2014). From Strengthening Administrative Capacity Building (ACB) to Public Sector Innovation (PSI): Building Blocks and Successful Bridges, Eipascope, European Institute of Public Administration EIPA. Retrieved from https://www.eipa.eu/wp-content/uploads/2018/03/EIPASCOPE_2014_web.pdf

- HRM Guide. (2011). the HR Role in Public Sector Reform. Retrieved from http://www.hrmguide.co.uk/strategic_hrm/public-sector-hr.htm

- HR Trend Institute. (2019). Applying Agile Practices - Agile Human Resources. Retrieved from https://tech.gsa.gov/guides/applying_agile_practices_HR/

- International Civil Service Effectiveness Index. (2017). Retrieved from https://www.instituteforgovernment.org.uk/publications/international-civil-service-effectivenessincise-index-2017

- IPMA-HR. (2016). HR 2020 Shifting Perspectives: A Vision for Public Sector HR. Retrieved from https://www.ipma-hr.org/docs/default-source/public-docs/ipmahr-files-nov28/nodedocuments/30655-hr-2020-report-final.pdf?sfvrsn=4d6f5aee_ 2

- IPMA-HR. (2017). Benchmarking Report: Culture of Innovation. Retrieved from https://www.ipma-hr.org/stay-informed/research-and-reports/benchmark-reports/2017-ipma-hrbenchmarking-report

- Iqbal,M.(2006). Is Good Governance an Approach to Civil Service Reforms? The Pakistan Development Review, Vol. 45 : 4 , No.2, pp. 621-637.Retrieved from http://www.pide.org.pk/pdf/PDR/2006/Volume4/621-637.pdf

- Jones, J. (2016). Managing Organizational Change with an HR Department of One, SHRM. Retrieved from https://www.shrm.org/resourcesandtools/hr-topics/behavioralcompetencies/relationship-management/pages/managing-organizational-change-with-an-hrdepartment-of-one.aspx

- Järvalt, J. (2012). Strategic Human Resource Management in the Public Service: Evidence from Estonia and Other Central and Eastern European Countries, (Doctoral thesis), Tallinn University of Technology, Estonia. Retrieved from https://digi.lib.ttu.ee/download/743/Strategic+Human+Resource+Management+in+the+Public+Se rvice\%3A+Evidence+from+Estonia+and+Other+Central+and+Eastern+European+Countries.pdf

- Järvalt, J., Randma-Liiv, T. (2010), Public sector HRM: the case of no central human resource strategy, Baltic Journal of Management, Vol. 5, No. 2, pp. 242-256. Retrieved from https://doi.org/10.1108/17465261011045142

- Knies, E., Boselie, P., Gould-Williams, J., Vandenabeele, W. (2018). Strategic human resource management and public sector performance: context matters, The International Journal of Human Resource Management, pp. 1-13. Retrieved from https://doi.org/10.1080/09585192.2017.1407088

- Krishna, G., Prasad, N. (2012). Transforming HR Professionals into Business Partners, European Journal of Business and Management, Vol. 4, No.4, pp.29-34. Retrieved from https://iiste.org/Journals/index.php/EJBM/article/view/1428/1353

- Lodge, G., Kalitowski, S. (2007). Innovations in Government: International perspectives on civil service reform, Institute for Public Policy Research IPPR, London, UK. Retrieved from https://www.ippr.org/files/images/media/files/publication/2011/05/innovations_in_government_1 $\underline{\text { 574.pdf }}$

- McKinsey \& Company. (2017). Government productivity, unlocking the $\$ 3.5$ trillion opportunity. Retrieved from https://www.mckinsey.com/industries/public-sector/our-insights/the-opportunityin-government-productivity

- Mercer. (2012). It's Time for the Next Generation HR Service Delivery Model. Retrieved from https://www.mercer.com/content/dam/mercer/attachments/global/Talent/AssessBrochureHRAssessment.pdf

- Mulholland, B. (2017). 8 Critical Change Management Models to Evolve and Survive. Retrieved from https://www.process.st/change-management-models/

- Naghibi, M., Baban, H. (2011). Strategic change management: The challenges faced by organizations, International Conference on Economics and Finance Research IPEDR Vol.4 IACSIT Press, Singapore. Retrieved from http://www.ipedr.com/vol4/108-F00035.pdf

- OECD. (2017). Skills for a High Performing Civil Service, OECD Public Governance Reviews, OECD Publishing, Paris. Retrieved from http://dx.doi.org/10.1787/9789264280724-en 
- OECD. (2015). Achieving Public Sector Agility at Times of Fiscal Consolidation, OECD Public Governance Reviews, OECD Publishing. Retrieved from http://dx.doi.org/10.1787/9789264206267-en

- Pazvakavambwa, A., Steyn G. M. (2014). Implementing Results-Based Management in the Public Sector of Developing Countries: What Should be considered? Mediterranean Journal of Social Sciences, Vol. 5, No. 20, pp.245- 257 .Retrieved from https://pdfs.semanticscholar.org/6060/666b4adae54349da3703a58db76a169c83d3.pdf

- Penger, S., Tekavčič, M. (2008). Slovenian case of strategic change management in the public sector: Towards the Lisbon Strategy, Zb. rad. Ekon. fak. Rij. Vol. 26, No. 2, pp.301-324. Retrieved from https://hrcak.srce.hr/file/48395

- Perry, J., Wise, L. (1990). The Motivational Bases of Public Service. Public Administration Review, Vol.50, No.3, pp.367-73. Retrieved from https://eric.ed.gov/?id=EJ406473

- Rigby, D. (2015). Management Tools, An executive's guide. Bain \& Company, Inc. Retrieved from

http://www.bain.de/Images/BAIN_GUIDE_Management Tools_2015_executives_guide.pdf

- Robinson, M. (2015). From Old Public Admiration to the New Public Service, Implications for Public Sector Reform in Developing Countries. UNDP, Global Center for Public Service Excellence GCPSE. Retrieved from https://www.undp.org/content/dam/undp/library/capacitydevelopment/English/Singapore\%20Centre/PS-Reform_Paper.pdf

- Roper, J. (2016). HR's role in organizational agility. HR Magazine. Retrieved from https://www.hrmagazine.co.uk/article-details/hrs-role-in-organisational-agility

- Rothwell, W., Prescott R., Taylor, M. (2008). Human Resource Transformation: Demonstrating Strategic Leadership in the Face of Future Trends. Nicholas Brealey Publishing. Retrieved from https://epdf.tips/human-resource-transformation-demonstrating-strategic-leadership-in-the-faceof-.html

- Shakya, R. (2009). Why Civil Service Reforms fail? - A Case of Nepal. Administration and Management Review, Vol. 21, No.2, pp. 40 - 63. Retrieved from http://citeseerx.ist.psu.edu/viewdoc/download?doi=10.1.1.896.945\&rep=rep1\&type=pdf

- Sylvester, O. (2008). The Rapid Results Approach/Initiative: Institutionalization of results based management in Kenya's public service. Cabinet Office- Office of the President, Government of Kenya Retrieved from https://pdfs.semanticscholar.org/add7/c73a3c2f6e2bc333dd13abdd9877bef9f42d.pdf?_ga=2.2132 53584.519213777.1566296534-777659817.1566296534

- Ulrich, D. Allen J., Bockbank W., Younger J., Nyman M. (2009).HR Transformation: Building Human Resources from the Outside In. McGraw Hill. Retrieved from http://www.academia.edu/29108680/Dave_Ulrich_2009_-HR_Transformation

- UNESCO. (2015). Results-Based Programming, Management, Monitoring and Reporting (RBM) approach as applied at UNESCO, Guiding Principles. Bureau of Strategic Planning, Paris. Retrieved from: http://unesdoc.unesco.org/images/0017/001775/177568E.pdf

- Van der Togt, J., Rasmussen, T. (2017). Toward evidence-based HR. Journal

- of Organizational Effectiveness: People and Performance, Vol. 4 No. 2, pp.127132.https://doi.org/10.1108/JOEPP-02-2017-0013

- Van Hoek, R., Harrison, A., Christopher, M. (2001). Measuring agile capabilities in the supply chain. International Journal of Operations \& Production Management, Vol. 21 No. 1/2, pp. 126148.http://dx.doi.org/10.1108/01443570110358495 